\title{
Variation in marine benthic community composition allows discrimination of multiple stressors
}

\author{
Hunter S. Lenihan ${ }^{1,4, *}$, Charles H. Peterson ${ }^{1}$, Stacy L. Kim ${ }^{2}$, Kathleen E. Conlan ${ }^{3}$, \\ Russell Fairey ${ }^{2}$, Christian McDonald ${ }^{2}$, Jonathan H. Grabowski ${ }^{1}$, John S. Oliver ${ }^{2}$ \\ ${ }^{1}$ The University of North Carolina at Chapel Hill, Institute of Marine Sciences, Morehead City, North Carolina 28557, USA \\ ${ }^{2}$ Moss Landing Marine Laboratories, 8272 Moss Landing Road, Moss Landing, California 95039, USA \\ ${ }^{3}$ Canadian Museum of Nature, PO Box 3443, Station D, Ottawa, Ontario K1P 6P4, Canada \\ ${ }^{4}$ Present address: Bren School of Environmental Science and Management, University of California, Santa Barbara, \\ California 93106, USA
}

\begin{abstract}
Predicting how communities respond to multiple, potentially interacting chemical stressors is inherently difficult because community structure and dynamics, the chemical properties of contaminants, and biological-chemical interactions vary with environmental conditions. Using a field experiment conducted in Antarctica, we tested whether 3 phyla of benthic soft-sediment marine invertebrates-annelids, arthropods, and echinoderms - respond differently to 2 common forms of contamination, organic enrichment and toxic contamination. Based on life history strategies and physiological tolerances to contaminants, we hypothesized that the principal responses of the 3 phyla would be: (1) enhanced abundance of annelids in organically enrichment sediments and (2) decreased abundance of arthropods and echinoderms in toxic metal contamination. Sediment treatments were established in the field experiment with an orthogonal combination of 3 levels of total organic carbon (TOC; 0,1 , and $2 \%$ by weight) and copper $\left(\mathrm{Cu}_{i} 0,100\right.$, and $500 \mu \mathrm{g} \mathrm{Cu} \mathrm{g}^{-1}$ sediment), and colonization patterns were observed after 1 yr. Densities of annelids (mainly polychaetes) increased with TOC across all levels of $\mathrm{Cu}$. Arthropods and echinoderms decreased with $\mathrm{Cu}$, but responded variably to TOC, based largely on differences in habitat preferences exhibited by epifaunal and infaunal species. Small subsurface arthropod species (amphipods, isopods, cumaceans, and ostracods) decreased in high organic loading, due to induction of and exposure to hypoxia and hydrogen sulfide, but large surface deposit-feeding echinoderms (asteroids and echinoids) responded positively to increased carbon food supply. We present a predictive model based on assessment of benthic community structure conducted at the taxonomic level of phyla that could be used to link cause and effect for multiple chemical stressors in marine ecosystems.
\end{abstract}

KEY WORDS: Antarctica - Multiple stressors - Chemical contaminants - Community response · Marine ecosystem $\cdot$ Organic enrichment $\cdot$ Invertebrates $\cdot$ Toxicants

Resale or republication not permitted without written consent of the publisher

\section{INTRODUCTION}

The discharge of anthropogenic chemical contaminants into the environment can have profound effects on natural ecosystems (Vitousek et al. 1997, Peterson 2001). Great strides have been made in detecting the biological effects of chemical contaminants on individual organisms, especially at molecular and cellular levels (Widdows 1985, Clarke et al. 1997). Identifying how chemical contaminants influence communities of organisms presents a much greater challenge because the chemical properties of contaminants, biologicalchemical interactions, and the demographic rates of impacted populations vary dramatically with environmental conditions (Underwood \& Peterson 1988, Schmitt \& Osenberg 1996). A better understanding of 
the ecological effects of pollutants and how they vary with environmental factors will improve our ability to detect and mitigate the impacts of anthropogenic activities in marine ecosystems.

Mixtures of biotic wastes, synthetic-organic compounds (e.g. polychlorinated biphenyls [PCBs] and pesticides), metals, hydrocarbons, and various inorganic chemicals are injected into the ocean from municipal and industrial outfalls, atmospheric fallout, rivers, spills, and many non-point discharges (e.g. groundwater seepage and stormwater runoff). These anthropogenic contaminants may accumulate in sediments of bays, estuaries, and nearshore coastal zones. As a result, coastal regions worldwide experience acute and chronic exposure to 2 generic types of marine pollutants: organic enrichment (organic carbon and nutrient loading) and toxicants (organic or inorganic compounds, heavy metals, and petroleum hydrocarbons; Long 2000). Environmental concentrations of organic enrichment and toxicants near both point and non-point discharges are often confounded in space and time, making their separate and combined biological effects difficult to detect, especially at the levels of population and community (Peterson et al. 1996).

Over $\$ 1$ billion US dollars are spent annually worldwide to monitor pollutants and their ecological impacts (NRC 1990). Current pollution monitoring programs assess organic enrichment and toxicity using a tripartite approach — the Sediment Triad — which entails a combination of chemical analyses, field-based community surveys, and laboratory toxicity tests (Long \& Chapman 1985). Community surveys assess the abundance and spatial distribution of sediment-dwelling macroinvertebrates ('benthos') because component species are sedentary, trophically diverse, and important in marine food webs (Lenihan \& Micheli 2001). Benthic communities integrate the effects of contaminants through physical contact with sediments, ingesting sediment, or bioaccumulating contaminants via food webs (Gray 1974). Chemical analyses of sediments and toxicity bioassays are used to help explain the results of the community surveys, although cause and effect relationships between contamination and community response are usually based on correlative and non-mechanistic evidence (Schmitt \& Osenberg 1996).

Models have been developed to predict how marine communities respond to single contaminant types but not to multiple contaminant stressors. Pearson \& Rosenberg (1978) synthesized the impacts of organic enrichment on marine benthos and found that total biomass, the relative proportion of deposit feeders, and abundance of species with 'opportunistic' life histories (e.g. high fecundity, short generation time, and rapid dispersal) increased in organically enriched sediments. How opportunistic species, including many species of polychaete, oligochaete, and nematode worms, respond when exposed to varying mixtures of organic enrichment and toxicants is unclear. Warwick \& Clarke (1993) developed multivariate analyses of benthos conducted at the taxonomic level of phyla that ranked the severity of various forms of disturbances, including wave action, sedimentation, or complex mixtures of chemical pollutants in 9 temperate latitude locations. The graphical model that Warwick \& Clarke generated from their analyses provided a novel means of predicting how soft-sediment benthos responds to multiple disturbance types. However, their model, like other pollution community indices (Raffaelli \& Mason 1981, Warwick 1986, Somerfield \& Clarke 1995, Maurer et al. 1999), does not distinguish impacts caused by specific chemicals or chemical classes, or by combinations of chemicals.

Here we present the results of a manipulative experiment conducted in Antarctica used to test whether the patterns of community response are so predictable as to provide a reliable means of inferring the nature of the stressors. We tested the hypothesis that changes of abundance in 3 benthic invertebrate phyla provide a powerful yet potentially cost-effective biological indicator that discriminates between the effects of the 2 generic classes of pollutants, i.e. organic enrichment and toxicants. Specifically, we predicted that marine Annelida would increase in abundance in response to sediment organic enrichment, while Arthropoda and Echinodermata would decrease in abundance when exposed to toxicants. According to our model, an increase in annelids, with or without increases in arthropods and echinoderms, signifies organic enrichment. In contrast, large decreases in arthropods and echinoderms, without an increase in annelids, signify the presence of toxicants. An increase in annelids with concomitant decreases in arthropods and echinoderms signifies the presence of both pollutant types. We use the results of the experiment to construct a general predictive model that could be used to link the response of marine benthos to varying levels and mixtures of organic enrichment and toxicants in marine ecosystems.

\section{MATERIALS AND METHODS}

Life history traits of marine benthic invertebrates. Our hypothesis is based on life history traits and physiological responses to enrichment and toxicants typically exhibited by the dominant species within each of the 3 phyla. Annelids rapidly colonize organically enriched areas because many species have opportunistic life histories and relatively high tolerance to some toxicants due to the in vivo production of detoxifying secondary metabolites and proteins (Marcano et 
al. 1996, Völkel \& Grieshaber 1997, Wallace et al. 1998). Nevertheless, in many intensely polluted areas, no annelids persist because the concentration of toxicants is too high to detoxify (Steichen et al. 1996). In contrast, there are relatively fewer species of arthropods and echinoderms with opportunistic life histories, and these phyla are more sensitive to toxic chemicals because they generally lack detoxification mechanisms (James 1989, Bryan \& Langston 1992, but see Nassir et al. 2000, Wallace et al. 2000). In sediments with high organic loading, very few macroorganisms persist in any phylum because of high microbial oxygen demand leading to hypoxia/anoxia and the production of toxic hydrogen sulfide (Fenchel \& Riedl 1970, Pearson \& Rosenberg 1978, Diaz \& Rosenberg 1995).

Experimental design. We tested our hypothesis with a field experiment conducted near McMurdo Station $\left(77^{\circ} 50^{\prime} \mathrm{S}, 166^{\circ} 40^{\prime} \mathrm{E}\right.$; Ross Island, McMurdo Sound), the major US research station in Antarctica. Nearshore marine habitats at McMurdo Station are continuously loaded with raw sewage and food refuse, causing organic enrichment (Lenihan et al. 1990, Lenihan 1992). Similar organic materials, along with paper and brewery distillates, hydrocarbons, and agricultural organic wastes are deposited on the seafloor in varying combinations worldwide. Benthic habitats at McMurdo Station have also been contaminated with PAHs, PCBs, and heavy metals, due to shipping activities and the dumping of industrial and scientific wastes (Lenihan et al. 1990, Risebrough et al. 1990). McMurdo Sound is an ideal location for conducting long-term field experiments on the shallowwater seafloor because intrinsic natural disturbances are minimized, wave action is reduced by sea ice, temperature variation is minimal, biological disturbance by large predators is lacking, riverine sedimentation is non-existent, and benthic invertebrate communities are abundant, well-described, and species-rich (Dayton et al. 1969, Dayton \& Oliver 1977, Lenihan \& Oliver 1995).

We used a manipulative field experiment to assess whether multiple contaminants and their interaction cause specific biological responses under natural environmental conditions. Our experiment allowed us to control contaminant levels, track environmental fluctuations, and quantify the impact of chemical changes on colonization and subsequent community structure after a 1 yr period. We employed a factorial experimental design to test separate and joint effects of total organic carbon (TOC) in sediments and copper $(\mathrm{Cu})$ on colonizing benthos. TOC and $\mathrm{Cu}$ were used as proxies for organic enrichment and toxicants, respectively. $\mathrm{Cu}$ was chosen because it is harmful to marine invertebrates (Furness \& Rainbow 1990), is an easy element to work with analytically, and is a toxicant at McMurdo Station (Lenihan et al. 1990). Sediment ( 375 l total) collected by divers at a pristine site (Cinder Cones, north of Knob Pt.; $9 \mathrm{~km}$ from McMurdo Station) was returned to the McMurdo Station laboratory, sieved through $1 \mathrm{~mm}$ mesh to remove debris and large fauna, and then defaunated by drying over a $7 \mathrm{~d}$ period at 30 to $42^{\circ} \mathrm{C}$. Subsamples of sediment were then spiked with either a solution of $\mathrm{CuSO}_{4}$, an organic carbon mixture (homogenized wheat flour, beans, and peas), or both, to create an orthogonal combination of 3 levels of $\mathrm{Cu}$ concentration $\left(0,100\right.$, and $500 \mu \mathrm{g} \mathrm{Cu} \mathrm{g}^{-1}$ sediment $)$ at each of 3 levels of TOC $(0,1$, and $2 \%$ by weight in sediments), creating 9 total sediment treatments. The $0 \mu \mathrm{g} \mathrm{Cu} \mathrm{g}^{-1}$ sediment treatment actually contained an ambient range of $\mathrm{Cu}$ concentrations (39 to $67 \mu \mathrm{g} \mathrm{Cu} \mathrm{g}^{-1}$ sediment) found in sediments at the pristine Cinder Cones site (Lenihan et al. 1990). Our organic carbon mix was used to mimic the 2 major organic enrichment sources at McMurdo Station, food refuse from the local galley and human sewage debris (Howington et al. 1992).

Spiked sediments were placed into plastic colonization trays $\left(440 \mathrm{~cm}^{2} \times 9 \mathrm{~cm}\right.$ deep; $\mathrm{n}=8$ of each treatment combination; 72 total) that were capped, moved, and subsequently uncapped after placement onto the seafloor. The colonization trays were installed on 5 to 17 November 1997 and retrieved on 17 to 23 November 1998. Divers placed the trays at $18 \mathrm{~m}$ water depth at Cinder Cones so that the tops of the side walls sat flush with the sediment surface. After 1 mo, 2 randomly selected trays from each sediment treatment were sampled for \% TOC, Cu concentration, and grain size using an acid-washed (trace metal clean), $4 \mathrm{~cm}$ diameter polyethylene core that was inserted to $5 \mathrm{~cm}$ depth, thus providing $63 \mathrm{~cm}^{3}$ of sediment sample. After $1 \mathrm{yr}$, trays were re-capped and brought back to the laboratory, where a sediment chemistry core was taken from every replicate, after which the remaining sediments were sampled for organisms by passing the sediments through $0.25 \mathrm{~mm}$ mesh. Animals were fixed with buffered $10 \%$ formalin, and later identified and counted under a dissecting microscope. Appropriate trace-metal clean procedures were used throughout the experiment. Chemical analyses and sediment grain size were analyzed by the Moss Landing Marine Pollution Laboratory: \% TOC was analyzed with a Perkin-Elmer elemental analyzer; bulk $\mathrm{Cu}$ levels were analyzed with Inductive Coupled Plasma Mass Spectrometry (ICPMS); and grain size analysis was conducted using a combination of sieve and hydrometer analysis.

Data analysis. Differences in \% TOC and sediment grain size (\% silt/clay) among the 9 sediment treatments were compared using 1-way ANOVA. A 2-way 
ANOVA was used to test whether $\mathrm{Cu}$ concentrations in trays varied with sediment treatment and sampling period (1 mo vs 1 yr of exposure), with Sediment treatment and Period as crossed, fixed factors. This test was conducted to determine whether $\mathrm{Cu}$ concentrations changed over the course of the experiment through dissolution, diagenesis, or other geochemical processes that could have changed the level of toxicity in the sediment treatments. A similar 2-way ANOVA was not conducted with \% TOC because samples were destroyed accidentally during shipment from Antarctica. A 2-way MANOVA was used to test whether the joint abundances of the 3 phyla varied in response to different concentrations of $\mathrm{TOC}, \mathrm{Cu}$, and their interaction. MANOVA was also used to test whether the joint abundances of specific invertebrate taxa (i.e. species) varied in response to different concentrations of TOC, $\mathrm{Cu}$, and their interaction. When significant differences were found in MANOVA, univariate ANOVA was used to test for differences in the response of each phylum or species to the sediment treatments. Prior to ANOVA and MANOVA, data were tested for hetero-

a
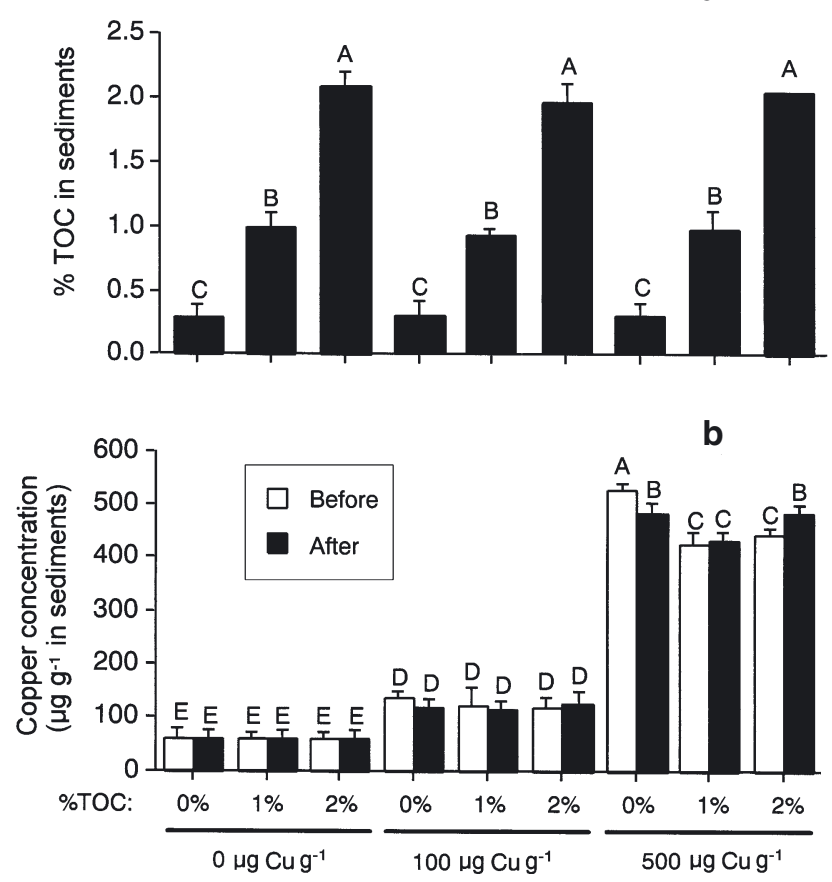

Fig. 1. Mean $( \pm \mathrm{SE})$ concentrations of (a) total organic carbon (TOC) and (b) copper $(\mathrm{Cu})$ in sediment treatments in colonization trays. \% TOC by weight in sediments was measured after $1 \mathrm{yr}$ of exposure on the seafloor. $\mathrm{Cu}$ concentrations (total $\mu \mathrm{g} \mathrm{Cu} \mathrm{g}{ }^{-1}$ dry weight of sediment) were measured after 1 mo (Before) and 1 yr (After) of exposure. $\mathrm{N}=2$ measurements per sediment treatment for each pollutant type. Results of SNK post-hoc tests are provided above each bar $(\mathrm{A}>\mathrm{B}>\mathrm{C}>\mathrm{D}>\mathrm{E}$ at $\mathrm{p}<0.05)$ geneity of variances using Cochran's test. Data for \% TOC, $\mathrm{Cu}$ concentration, and sediment grain size had homogeneous variances. Data from the MANOVA of invertebrate abundances (phyla and species) had heterogeneous variances and were square-root transformed. Transformed data passed subsequent Cochran's tests for homogeneity of variances $\left(C_{\text {critical }}=0.44\right.$; $C=0.29-0.41 ; \mathrm{p}>0.05)$. After ANOVA, differences between specific treatments were determined with Student-Newman-Keuls (SNK) post-hoc tests $(\alpha=0.05)$.

\section{RESULTS}

\section{Chemical analyses}

Concentrations of TOC and $\mathrm{Cu}$, and sediment grain size changed little in the colonization trays over 1 yr of exposure on the seafloor (Fig. 1). Levels of \% TOC in sediments (with or without $\mathrm{Cu}$ ) measured after 1 yr in November 1998 were significantly different among the 3 TOC treatments (1-way ANOVA; $F_{8,9}=202.35 ; \mathrm{MS}=1.16 ; \mathrm{p}=0.0001 ; 0 \%<1 \%<2 \%$; SNK tests, $\mathrm{p}<0.05$ ), regardless of $\mathrm{Cu}$ level (Fig. 1a). Over the course of the experiment, $100 \mu \mathrm{g} \mathrm{Cu} \mathrm{g}{ }^{-1}$ sediment treatments ranged from 115 to $147 \mu \mathrm{g}$ total $\mathrm{Cu} \mathrm{g}^{-1}$ sediment, and $500 \mu \mathrm{g} \mathrm{Cu} \mathrm{g}{ }^{-1}$ sediment treatments ranged from 418 to $529 \mu \mathrm{g}$ total $\mathrm{Cu} \mathrm{g}^{-1}$ sediment . All $\mathrm{Cu}$ concentrations measured in the 100 and $500 \mu \mathrm{g} \mathrm{Cu} \mathrm{g}{ }^{-1}$ sediment treatments are considered toxic to marine organisms by the US EPA based on results of standardized laboratory toxicity bioassay tests using marine amphipods (US EPA 2000). The $0 \mu \mathrm{g} \mathrm{Cu} \mathrm{g}^{-1}$ sediment $\mathrm{Cu}$ treatments maintained $\mathrm{Cu}$ concentrations ranging from 57 to $66 \mu \mathrm{g} \mathrm{Cu} \mathrm{g}{ }^{-1}$ sediment, levels considered non-toxic to marine organisms by the US EPA (Fig. 1b; US EPA 2000).

Concentrations of $\mathrm{Cu}$ in colonization trays sampled after both 1 mo and 1 yr of exposure varied significantly with the interaction of sediment treatment and period (2-way ANOVA; Sediment treatment $\times$ Period interaction, $F_{8,18}=3.42 ; \mathrm{MS}=385.63 ; \mathrm{p}=0.01$ ). This interaction was due to variation in $\mathrm{Cu}$ levels among the $500 \mu \mathrm{g} \mathrm{Cu} \mathrm{g}^{-1}$ sediment treatments (SNK, p $<0.05$; Fig. 1b). Variation among the $500 \mu \mathrm{g} \mathrm{Cu} \mathrm{g}^{-1}$ sediment treatments may have resulted from incomplete mixing (i.e. spatial variation) of $\mathrm{Cu}$ within the original $125 \mathrm{l}$ batch of sediment used to create this sediment treatment. Levels of $\mathrm{Cu}$ in the 0 and $100 \mu \mathrm{g} \mathrm{Cu} \mathrm{g}^{-1}$ sediment treatments did not change significantly with sediment treatment or period (SNK tests, $\mathrm{p}>0.05$ ). Cu concentration was greatest in the $500 \mu \mathrm{g} \mathrm{Cu} \mathrm{g}{ }^{-1}$ sediment treatment, and was greater in the $100 \mu \mathrm{g} \mathrm{Cu} \mathrm{g}^{-1}$ sediment treatments than in the $0 \mu \mathrm{g} \mathrm{Cu} \mathrm{g}^{-1}$ sediment treatments (SNK, p < 0.05). 
Sediment grain size (\% silt/clay) did not differ among treatments (1-way ANOVA, $F_{8,9}=2.90, \mathrm{MS}=$ $0.59 ; \mathrm{p}=0.07$ ) at the end of the experiment. The \% silt/clay in all treatments ranged from 5.44 to 7.53 , levels similar to those previously sampled in ambient sediments at Cinder Cones (Lenihan et al. 1990, Lenihan \& Oliver 1995).

Hypoxia/anoxia and hydrogen sulfide appeared to be present in all replicates of the $2 \%$ TOC treatment, because subsurface sediments smelled like sulfide, changed color from black to gray with depth (indicative of reducing conditions), and sediment surfaces supported colonies of a white bacterium, probably Beggitoa sp., which thrives on sulfide flux (Kowallik \& Pringshe 1966, Fenchel \& Bernard 1995). Most of the replicates of the $1 \%$ TOC also released a faint sulfide odor but did not support a white bacterial growth.

\section{Community response}

Experimental trays were colonized by high densities of annelids (polychaete and oligochaete worms), arthropods (amphipods, tanaids, isopods, ostracods, and harpacticoid copepods), and echinoderms (epifaunal asteroids and both epifaunal and infaunal echinoids) that inhabit the Cinder Cones community. Except for the echinoderms, many of the organisms were small (0.2 to $4.0 \mathrm{~mm}$ ) deposit-feeding, suspension-feeding, or predatory infaunal species that colonized either by larval settlement or immigration. Trays were also colonized by molluscs, nemerteans, cnidarians, and a large (2 to $5 \mathrm{~mm}$ diameter) protist, Gromia oviformis Dujardin.

Results of MANOVA followed by univariate ANOVAs revealed that annelid, arthropod, and echinoderm abundance varied with both pollutants and their interaction (Table 1).
Annelids

Annelid abundance increased significantly with TOC at each $\mathrm{Cu}$ concentration (Fig. 2a; SNK, p < 0.05), but also decreased significantly with increasing $\mathrm{Cu}$ concentration (SNK, $\mathrm{p}<0.05)$. That is, annelids at the highest TOC concentration (2\%) decreased with increasing $\mathrm{Cu}$. In addition, there were fewer annelids at $1 \%$ TOC $\times 500 \mu \mathrm{g} \mathrm{Cu} \mathrm{g}{ }^{-1}$ sediment than at $1 \%$ TOC $\times 0 \mu \mathrm{g} \mathrm{Cu} \mathrm{g}^{-1}$ sediment and $1 \%$ TOC $\times 100 \mu \mathrm{g} \mathrm{Cu}$ $\mathrm{g}^{-1}$ sediment $(\mathrm{SNK}, \mathrm{p}<0.05)$. Finally, there were more annelids in the most polluted sediments $(2 \%$ TOC $\times$ $500 \mu \mathrm{g} \mathrm{Cu} \mathrm{g}^{-1}$ sediment) than in unpolluted (i.e. $0 \%$ TOC $\times 0 \mu \mathrm{g} \mathrm{Cu} \mathrm{g}^{-1}$ sediment) control treatments (SNK, $\mathrm{p}<0.05)$. Overall, differences in TOC explained a majority $(62 \%)$ of the variation in annelid abundance across all treatments (Table 1).

Variation in the abundance of annelids among treatments was driven by 3 species of polychaete worms: Spiophanes tcherniai Fauvel (family: Spionidae), Capitella perarmata Gravier (Capitellidae), and Ophryotrocha notialis Ehlers (Dorvilleidae) (Table 2). These species accounted for more than $90 \%$ of the biomass of annelid species in the experiment (authors' unpubl. data). The tube-building, facultative suspension feeder $S$. tcherniai was the most abundant species in unpolluted and less-polluted sediments. Abundance of $S$. tcherniai varied with $\mathrm{TOC}, \mathrm{Cu}$, and their interaction across treatments (MANOVA, Wilk's lambda = $0.001, F=13.41, \mathrm{p}=0.0001 ;$ ANOVA, TOC $\times \mathrm{Cu}, \mathrm{MS}=$ $\left.218.63, F_{4,54}=16.76, \mathrm{p}=0.001\right]$. There was no difference in the density of $S$. tcherniai between the $0 \%$ TOC $\times 0 \mu \mathrm{g} \mathrm{Cu} \mathrm{g}^{-1}$ and $0 \%$ TOC $\times 100 \mu \mathrm{g} \mathrm{Cu} \mathrm{g}^{-1}$ sediment treatments $(\mathrm{SNK}, \mathrm{p}>0.05)$, but both of these treatments had more $S$. tcherniai than any other treatment (SNK, p < 0.05). There were no significant differences in $S$. tcherniai among any other treatments

Table 1. Results of MANOVA comparing the abundance of annelids (A), arthropods (Ar), and echinoderms (E) in contaminated sediments after $1 \mathrm{yr}$ of exposure at Cinder Cones in McMurdo Sound, Antarctica. MANOVA tested whether the 3 response variables varied together as a function of total organic carbon in sediments (TOC; 0,1 , and $2 \%)$, copper $\left(\mathrm{Cu}_{i} 0,100,500 \mu \mathrm{g} \mathrm{Cu} \mathrm{g}{ }^{-1}\right.$ sediment), and their interaction (see 'Results' for actual concentrations of TOC and $\mathrm{Cu}$ spiked sediments). Shown also are the subsequent univariate ANOVAs for each response variable. $\mathrm{df}=$ degrees of freedom; $F=F$-ratio; $\mathrm{p}=\mathrm{p}$-value; Total SS $=$ total sum of squares for each ANOVA; Partial $\mathrm{r}^{2}=\mathrm{SS}$ for each model/total SS

\begin{tabular}{|c|c|c|c|c|c|c|c|c|c|c|c|c|c|}
\hline \multirow[t]{2}{*}{ Source } & \multirow[t]{2}{*}{$\mathrm{df}$} & \multicolumn{3}{|c|}{ Annelids (A) } & \multicolumn{3}{|c|}{$\begin{array}{l}\text { - Univariate ANOVAs } \\
\text { Arthropods (Ar) }\end{array}$} & \multicolumn{3}{|c|}{ Echinoderms (E) } & \multicolumn{3}{|c|}{$\begin{array}{c}-\mathrm{MANOVA}- \\
(\mathrm{A}, \mathrm{Ar}, \mathrm{E})\end{array}$} \\
\hline & & $F$ & $\mathrm{p}$ & $\begin{array}{l}\text { Partial } \\
\mathrm{r}^{2}\end{array}$ & $F$ & $\mathrm{p}$ & $\begin{array}{l}\text { Partial } \\
\mathrm{r}^{2}\end{array}$ & $F$ & $\mathrm{p}$ & $\begin{array}{l}\text { Partial } \\
\mathrm{r}^{2}\end{array}$ & $\begin{array}{c}\text { Wilk's } \\
\text { lambda value }\end{array}$ & $F$ & $\mathrm{p}$ \\
\hline TOC & 2 & 88.63 & 0.0001 & 0.62 & 44.30 & 0.0001 & 0.18 & 11.47 & 0.0001 & 0.05 & 0.07 & 34.21 & 0.0001 \\
\hline $\mathrm{Cu}$ & 2 & 13.53 & 0.0001 & 0.09 & 138.56 & 0.0001 & 0.56 & 190.30 & 0.0001 & 0.81 & 0.04 & 48.28 & 0.0001 \\
\hline $\mathrm{TOC} \times \mathrm{Cu}$ & 4 & 6.65 & 0.0002 & 0.09 & 18.15 & 0.0001 & 0.15 & 3.00 & 0.03 & 0.02 & 0.14 & 8.65 & 0.0001 \\
\hline Residual & 54 & & & & & & & & & & & & \\
\hline Total df: & 62 & Total SS & 166.22 & & & 680.35 & & & 59.78 & & & & \\
\hline
\end{tabular}



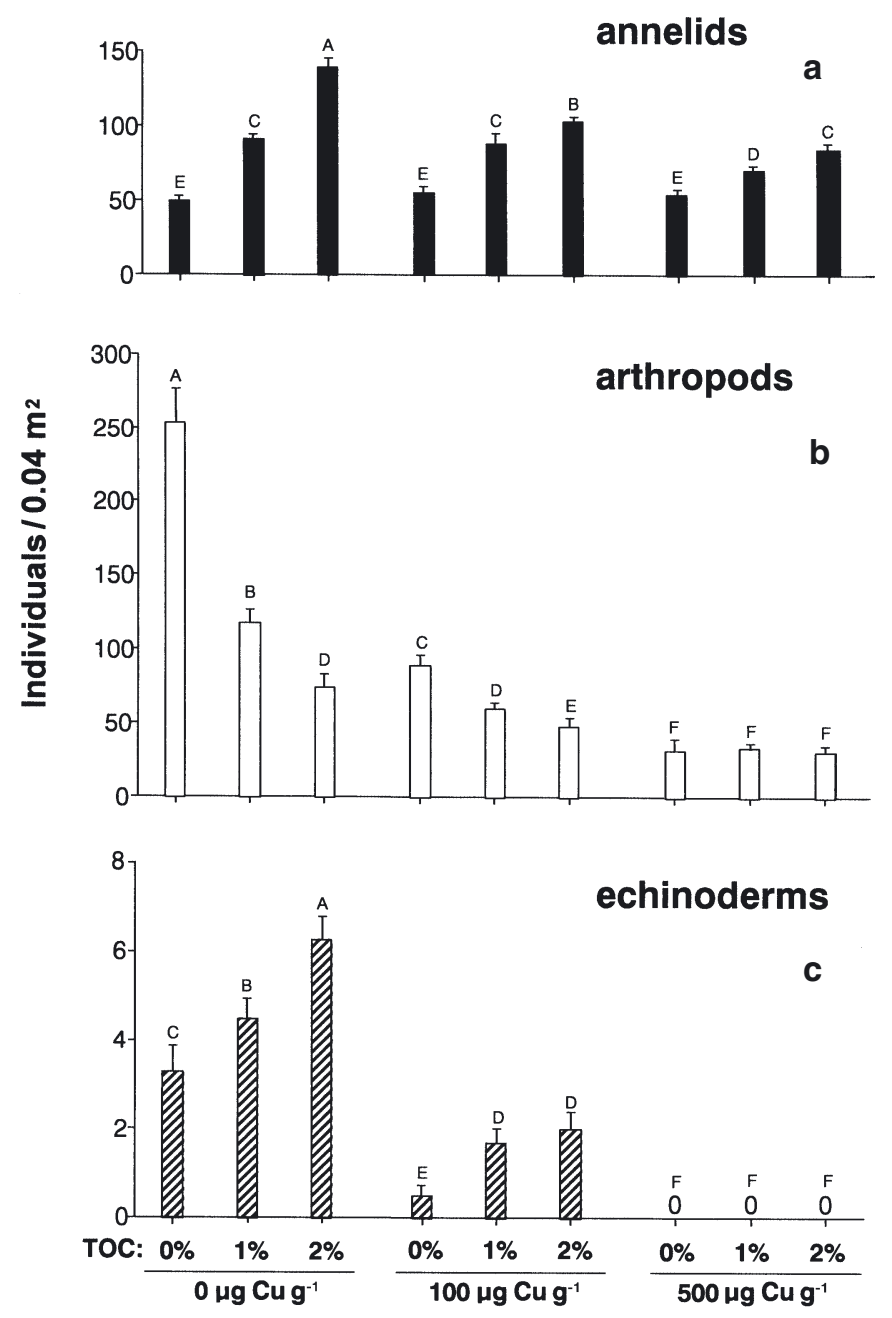

Fig. 2. Mean ( \pm SE) densities of (a) annelids, (b) arthropods, and (c) echinoderms recovered in colonization trays containing pollutant-treated sediments at Cinder Cones in McMurdo Sound, Antarctica, in 1998. Actual concentrations of TOC and $\mathrm{Cu}$ are provided in Fig. 1. $\mathrm{N}=8$ replicate colonization trays per sediment treatment. Results of SNK post-hoc tests are provided above each bar $(\mathrm{A}>\mathrm{B}>\mathrm{C}>\mathrm{D}>\mathrm{E}<\mathrm{F}$ at $\mathrm{p}<0.05)$

(SNK, p > 0.05). Capitella perarmata and Ophryotrocha notialis were the most abundant species in treatments containing $\mathrm{TOC}, \mathrm{Cu}$, or their combination (Table 2). The abundance of $C$. perarmata, a near surface deposit-feeder, varied with $\mathrm{TOC}, \mathrm{Cu}$, and their interaction (MANOVA, Wilk's lambda $=0.001, F=$ 13.41, $\mathrm{p}=0.0001 ;$ ANOVA, TOC $\times \mathrm{Cu}, \mathrm{MS}=2289.00$, $\left.F_{4,54}=13.00, \mathrm{p}=0.0001\right)$. The pattern of $C$. perarmata abundance was complex: in general, they increased with TOC at each level of $\mathrm{Cu}$, but this relationship decreased with increasing $\mathrm{Cu}$ concentration (SNK, $\mathrm{p}<$ 0.05). The abundance of $O$. notialis, also a near surface deposit-feeder, varied with TOC, $\mathrm{Cu}$, and their interaction as well (MANOVA, Wilk's lambda $=0.001, F=$ 13.41, $\mathrm{p}=0.0001 ;$ ANOVA, TOC $\times \mathrm{Cu}, \mathrm{MS}=425.71$,
$\left.F_{4,54}=7.50, \mathrm{p}=0.0001\right)$. The number of $O$. notialis was higher in $1 \%$ TOC $\times 0 \mu \mathrm{g} \mathrm{Cu} \mathrm{g}^{-1}$ sediment, $2 \% \mathrm{TOC} \times$ $0 \mu \mathrm{g} \mathrm{Cu} \mathrm{g}^{-1}$ sediment, and $2 \%$ TOC $\times 100 \mu \mathrm{g} \mathrm{Cu} \mathrm{g}^{-1}$ sediment than the other treatments (SNK, p $<0.05$; Table 2). There were fewer O. notialis in the $0 \%$ TOC $\times 0 \mu \mathrm{g} \mathrm{Cu} \mathrm{g}^{-1}$ sediment and $0 \%$ TOC $\times 100 \mu \mathrm{g} \mathrm{Cu} \mathrm{g}^{-1}$ sediment treatments than all other treatments (SNK, p $<0.05$ ), and there was no difference in abundance among the 3 TOC levels within the $500 \mu \mathrm{g} \mathrm{Cu} \mathrm{g}^{-1}$ sediment treatments (SNK, $\mathrm{p}>0.05)$.

\section{Arthropods}

Arthropod abundance decreased consistently with $\mathrm{Cu}$ at all levels of TOC, but also decreased with TOC in the 0 and $100 \mu \mathrm{Cu} \mathrm{g}^{-1}$ sediment treatments (SNK tests, $\mathrm{p}<0.05$; Fig. 2b). The number of arthropods did not vary with the level of TOC in $500 \mu \mathrm{g} \mathrm{Cu} \mathrm{g}^{-1}$ sediment treatments (SNK, p > 0.05), but there were significantly fewer arthropods in the $500 \mu \mathrm{g} \mathrm{Cu} \mathrm{g}{ }^{-1}$ sediment treatments than in all other treatments (SNK, $\mathrm{p}<0.05)$. This pattern of variation, characterized by decreasing abundance with both $\mathrm{Cu}$ and TOC levels (except at $500 \mu \mathrm{g}$ $\mathrm{Cu} \mathrm{g}^{-1}$ sediment ) produced a significant interaction in the ANOVA (Table 1). Overall, Cu levels explained a majority $(56 \%)$ of the variation in arthropod abundance among treatments (Table 1).

Patterns in arthropod abundance were driven mainly by changes in the density of the tanaid Nototanais dimorphus Beddard, the cumacean Eudorella splendida Zimmer, the isopod Austrosignum grande Beddard, and the amphipods Heterophoxus videns Walker and Monoculodes sp. (undescribed). These species accounted for more than $90 \%$ of arthropod biomass in the experiment (authors' unpubl. data). N. dimorphus, a tube-building predator, was the most abundant arthropod in all treatments (Table 2), and its density varied with $\mathrm{TOC}, \mathrm{Cu}$, and the interaction of the 2 pollutants (MANOVA, Wilk's lambda $=0.001, F=13.41, \mathrm{p}=$ 0.0001; ANOVA, TOC $\times \mathrm{Cu}, \mathrm{MS}=2326.18, F_{4,54}=$ $35.10, \mathrm{p}=0.0001$ ). There were many more $N$. dimorphus in the $0 \%$ TOC $\times 0 \mu \mathrm{Cu} \mathrm{g}^{-1}$ sediment and $1 \%$ TOC $\times 0 \mu \mathrm{g} \mathrm{Cu} \mathrm{g}^{-1}$ sediment treatments than in any of the other treatments (SNK, p $<0.05$; Table 2). There were also more $N$. dimorphus in the $0 \%$ TOC $\times 100 \mu \mathrm{g}$ $\mathrm{Cu} \mathrm{g}^{-1}$ sediment treatment in than any of the remaining treatments (SNK, p < 0.05). There were significantly fewer $N$. dimorphus in the 3 treatments with $500 \mu \mathrm{g} \mathrm{Cu}$ $\mathrm{g}^{-1}$ sediment, and the $2 \% \mathrm{TOC} \times 100 \mu \mathrm{g} \mathrm{Cu} \mathrm{g}{ }^{-1}$ sediment treatment than in any of the other treatments (SNK, $\mathrm{p}<0.05)$. The cumacean E. splendida, a depositfeeder, was most abundant in the $0 \%$ TOC $\times 0 \mu \mathrm{g} \mathrm{Cu}$ $\mathrm{g}^{-1}$ sediment treatment (MANOVA, Wilk's lambda $=$ $0.001, F=13.41, \mathrm{p}=0.0001 ;$ ANOVA, TOC $\times \mathrm{Cu}, \mathrm{MS}=$ 


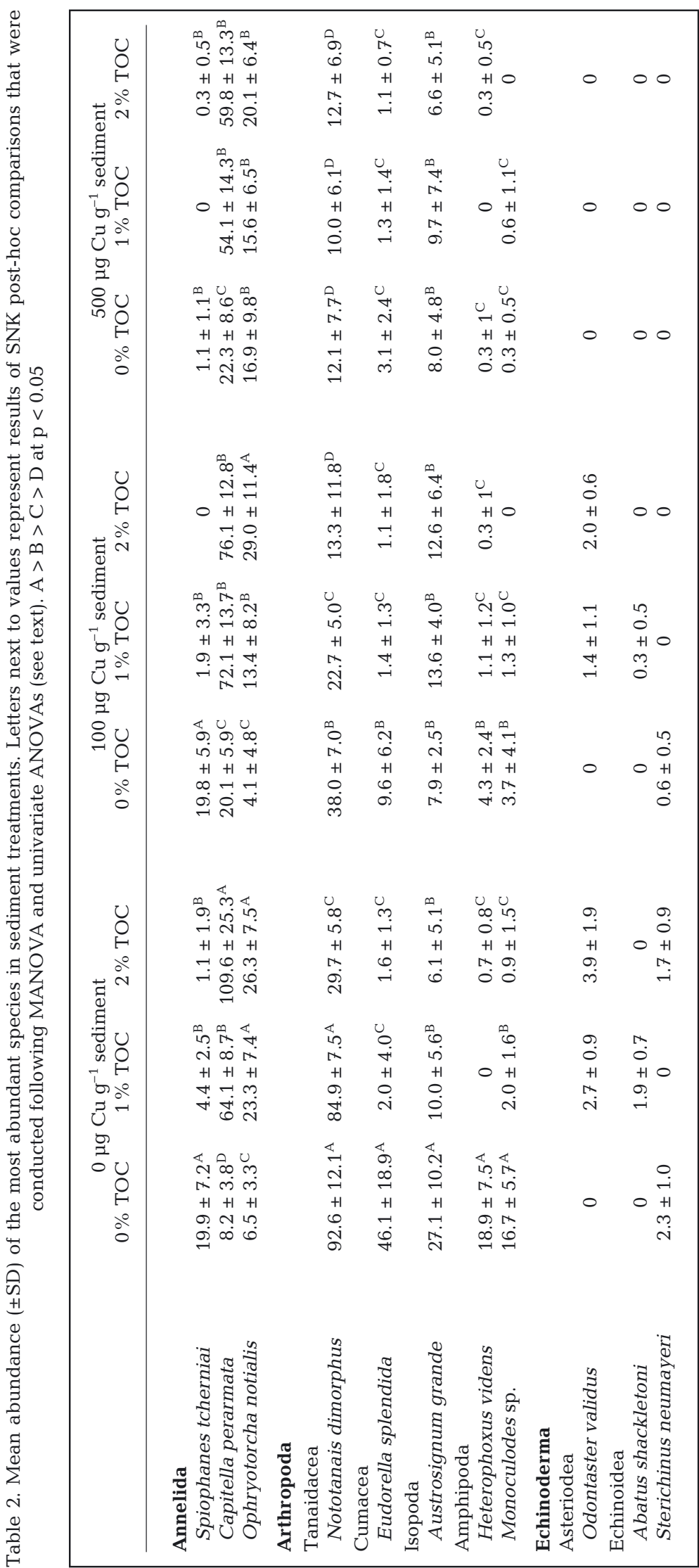

$1221.82, F_{4,54}=25.79, \mathrm{p}=0.0001 ; \mathrm{SNK}_{,} \mathrm{p}<$ 0.05 ; Table 2). The $0 \%$ TOC $\times 100 \mu \mathrm{g} \mathrm{Cu}$ $\mathrm{g}^{-1}$ sediment treatment had more $E$. splendida than any of the remaining treatments (SNK, $\mathrm{p}<0.05)$. There were no other differences among treatments (SNK, p < 0.05). The abundance of $A$. grande, another deposit-feeder, showed a pattern similar to E. splendida (MANOVA, Wilk's lambda $=0.001, F=$ $13.41, \mathrm{p}=0.0001 ;$ ANOVA, TOC $\times \mathrm{Cu}, \mathrm{MS}$ $=386.81, F_{4,54}=10.65, \mathrm{p}=0.0001 ;$ SNK, $\mathrm{p}$ $<0.05$; Table 2 ), except that there were no differences among treatments excluding the $0 \%$ TOC $\times 0 \mu \mathrm{g} \mathrm{Cu} \mathrm{g}^{-1}$ sediment treatment, which had a higher abundance than any other treatment (SNK, $\mathrm{p}<0.05$ ). The density of $H$. videns, a predatory amphipod that preys on small soft-bodied infauna (Oliver \& Slattery 1985), varied with TOC, $\mathrm{Cu}$, and their interaction (MANOVA, Wilk's lambda $=0.001, F=$ $13.41, \mathrm{p}=0.0001 ;$ ANOVA, TOC $\times \mathrm{Cu}$, MS $\left.=207.54, F_{4,54}=29.92, \mathrm{p}=0.0001\right)$, as did the density of Monoculodes sp., an omnivorous amphipod (MANOVA, Wilk's lambda $=0.001, F=13.41, \mathrm{p}=0.0001$; ANOVA, TOC $\times \mathrm{Cu}, \mathrm{MS}=152.24, F_{4,54}=$ $24.06, p=0.0001)$. Like the cumacean and isopod, the 2 species of amphipods were far more abundant in the $0 \%$ TOC $\times 0 \mu \mathrm{g}$ $\mathrm{Cu} \mathrm{g}^{-1}$ sediment treatment than any of the other treatments (SNK, $\mathrm{p}<0.05$; Table 2).

\section{Echinoderms}

Echinoderm abundance decreased with increasing $\mathrm{Cu}$ levels at all levels of TOC (SNK, p $<0.05$; Fig. 2c), and no echinoderms were found in the $500 \mu \mathrm{g} \mathrm{Cu} \mathrm{g}^{-1}$ sediment treatment. In contrast to arthropods, echinoderms increased with TOC at the 2 lower $\mathrm{Cu}$ concentrations (SNK, $\mathrm{p}<$ 0.05). Nevertheless, $81 \%$ of the variation in echinoderms among treatments was explained by differences in $\mathrm{Cu}$ (Table 1).

Echinoderms colonizing the experiments were the large, epifaunal, highly mobile deposit-feeding asteroid Odontaster validus Koehler, the epifaunal urchin Sterichinus neumayeri Meissner, and the shallowsubsurface deposit-feeding heart urchin Abatus shakletoni Koehler (Table 2). All 3 species are 
attracted to and react quickly to organic enrichment in McMurdo Sound (Dayton et al. 1974). Most O. validus and $S$. neumayeri individuals were quite large (4 to $13 \mathrm{~cm}$ diameter), indicating that they colonized the trays by immigration as opposed to larval settlement. Some of the A. shakletoni were small juveniles, indicating that they had recruited to treatments as larvae. Statistical analyses were not conducted on echinoderm abundance, because they were not found in many of the treatments. For example, no echinoderms were found in treatments with $500 \mu \mathrm{g} \mathrm{Cu} \mathrm{g}^{-1}$ sediment .

\section{DISCUSSION}

The results of our manipulative field experiment indicated that annelids (mainly polychaete worms with opportunistic life history strategies from the families Capitellidae, Dorvilleidae, Orbinidae, and Spionidae) respond positively to organic enrichment at all but the highest levels of toxic contamination, and that arthropods and echinoderms respond negatively to toxicants with or without co-occurring organic enrichment. The positive response of annelids to organic enrichment has long been recognized (e.g. Pearson \& Rosenberg 1978). Our results are novel because we reveal how 3 major benthic phyla, including annelids, respond collectively to separate and interactive effects of organic enrichment and toxicants. We predicted the results of our experiment based on well-known, intrinsic genetic (Grassle \& Grassle 1974), physiological (Widdows 1985, Gierse et al. 1999), behavioral (Oakden et al. 1984a,b), and ecological (Gray 1974, Dayton \& Oliver 1977, Heip et al. 1985, Warwick 1986, 1988, Gray et al. 1990, Lenihan \& Oliver 1995) differences among higher taxa of marine soft-sediment invertebrates.

The dominant signal for all phyla in our field experiment was response to a single factor: annelids increased with TOC, and both arthropods and echinoderms declined with $\mathrm{Cu}$. However, results also showed that the interaction, or combined effects, of the 2 pollutant types influenced community response. For example, annelids increased with TOC but also decreased in the highest concentration of $\mathrm{Cu}$, indicating the negative effect of exposure to high levels of toxic contamination. Arthropods decreased with toxic contamination, but also responded negatively to high levels of organic enrichment. Arthropods probably responded negatively to increasing TOC because most species were subsurface-dwelling amphipods, isopods, and cumaceans that were exposed to hypoxia/anoxia or toxic hydrogen sulfide (authors' pers. obs.), both of which result from the microbial decomposition of organic material. Pollution effects were also modified by the burrowing depth of the fauna. Arthropods re- sponded negatively to increasing organic enrichment, but echinoderms responded positively. The positive response of echinoderms to organic enrichment was driven mainly by the asterioid Odontaster validus and urchin Sterichinus neumayeri, both surface-dwelling deposit-feeders capable of avoiding toxic or hypoxic subsurface conditions. Both species of echinoderms also thrive on organic enrichment (Lenihan et al. 1995).

The pattern of response to $\mathrm{TOC}, \mathrm{Cu}$, and the combination of the 2 pollutants exhibited by the 3 phyla is clearly explained by examining the life histories of the most abundant species (Table 2). The most numerous annelids in unpolluted treatments were Spiophanes tcherniai, a deep-burrowing, tube-building suspension-feeder that is commonly found in eutrophic areas of McMurdo Sound (Lenihan \& Oliver 1995). S. tcherniai, and other spionid polyhaetes, are found throughout the world in sediments with low to moderate levels of organic carbon and are rarely found in oligtrophic areas (Fauchauld 1977). In contrast, Capitella perarmata and Ophryotrocha notialis are the most common genera of polychaetes found in organically enriched sediments in Antarctica (Lenihan \& Oliver 1995) and in other regions of the world (e.g. Pearson \& Rosenberg 1978). The pattern of response exhibited by the arthropod species was probably related to their physiological sensitivity, trophic level, and/or depth within the sediment in which the organism lives. The most abundant amphipods (Heterophoxus videns and Monoculodes sp.) inhabit subsurface sediments, so were well exposed to $\mathrm{Cu}$ toxicity and to hypoxic conditions in highly enriched treatments. Consequently, few amphipods were found in treatments with $2 \%$ TOC or with $500 \mu \mathrm{g} \mathrm{Cu} \mathrm{g}^{-1}$ sediment (Table 2). The observed response of amphipods was also expected because $H$. videns and Monoculodes sp. (and many other amphipod species from other regions on earth) are sensitive to toxic contaminants: both species had high rates of mortality when exposed to hydrocarbon and metal contaminated sediments from McMurdo Station in laboratory and field bioassay tests (Lenihan et al. 1995). The most abundant arthropods (Notanais dimorphus, Eudorella splendida, and Austrosignum grande) are all mostly surface-dwelling species, and the latter 2 species are deposit-feeders. All 3 species were found in all treatments, probably because they escaped somewhat from toxic exposure as surface dwellers. In addition, E. splendida and A. grande were probably attracted to organic enrichment.

\section{General model of community response}

Organically enriched sediments support communities with elevated numbers of annelids (relative to uncontaminated sites; see Pearson \& Rosenberg 1978), 
while arthropods and echinoderms either exhibit little change, or small increases due to enhanced food availability (Table 3 ). However, in highly enriched sediments, arthropods decline because of hypoxia/anoxia and exposure to hydrogen sulfide. In toxicant-contaminated sediments, arthropods and echinoderms are greatly diminished in abundance, with little change or small reductions in annelids. In sediments with both forms of contamination, annelid abundance increases (although with a lower magnitude than in enrichedonly sediments), while the abundances of both arthropods and echinoderms decline. Declines in all 3 phyla are probable in sediments with high levels of TOC and/or toxicants because (1) hypoxia/anoxia and toxic hydrogen sulfide are produced in highly enriched sediments (Fenchel \& Riedl 1970) and (2) most animals are not able to detoxify or tolerate extremely high levels of many toxicants.

Efforts to monitor, assess, and protect natural systems from contaminant exposure is beginning to shift from a single-contaminant, single-species emphasis toward identifying how multiple contaminants (or disturbances) influence whole communities at varying spatial scales (e.g. Clarke et al. 1997, US EPA 2000, Peterson 2001). Pollution community indices used today provide a measure of the magnitude of community disturbance (Raffaelli \& Mason 1981, Warwick 1986, Somerfield \& Clarke 1995, Maurer et al. 1999) but allow only weak inference about causes. In contrast, our qualitative model provides a potential means of directly linking specific types (TOC and $\mathrm{Cu}$ ) and even broad levels of generic pollutant types (organic enrichment and toxicants) with changes in multi-species assemblages. Use of a finer taxonomic scale than phyla, especially trophic group, may improve the accu- racy of predicting and recognizing community responses to specific contaminant types (H. S. Lenihan \& C. H. Peterson unpubl. data). Nevertheless, our results indicate that at the coarse taxonomic level of phyla, community responses to the separate and combined effects of the 2 major pollutant types are predictable and fairly easy to identify. We suggest that the predictions of our community response model be tested in other marine ecosystems with manipulative experiments as well as meta-analysis of data collected in pollution monitoring programs.

How are adequate control sites to be located in a monitoring program with which to compare presumptive impacted communities using our model based on relative abundances of the 3 phyla? Coastal marine pollution monitoring programs with the most powerful field assessment designs include sampling sites with high, medium, and low levels of contamination that share similar environmental conditions (e.g. Before-AfterControl-Impact-Paired Series designs; see Schmitt \& Osenberg 1996). However, most monitoring programs do not include spatio-temporal pairing of environmentally similar control and impact sites but, instead, contain stations located along gradients of decreasing impacts. Our model for detecting community impacts of organic enrichment and toxicants can be used with either approach. Descriptions of community patterns from relatively pristine sites or ends of contamination gradients provide the best available biological background, specifically the phylum level structure of infaunal communities, with which communities at impacted sites should be compared. Of course, obvious differences in environmental conditions (e.g. salinity, flow, and sediment type) among sites must be considered and controlled. For systems where adequate control sites or gradient ends are

Table 3. Relative changes in the abundance of soft-sediment macrofaunal annelids, arthropods, and echinoderms in response to organic enrichment, toxic contamination, and a combination of both forms of pollution. Abundance changes are those relative to reference communities in uncontaminated sediments with similar environmental conditions and species pool. Arrows denote large changes relative to reference communities

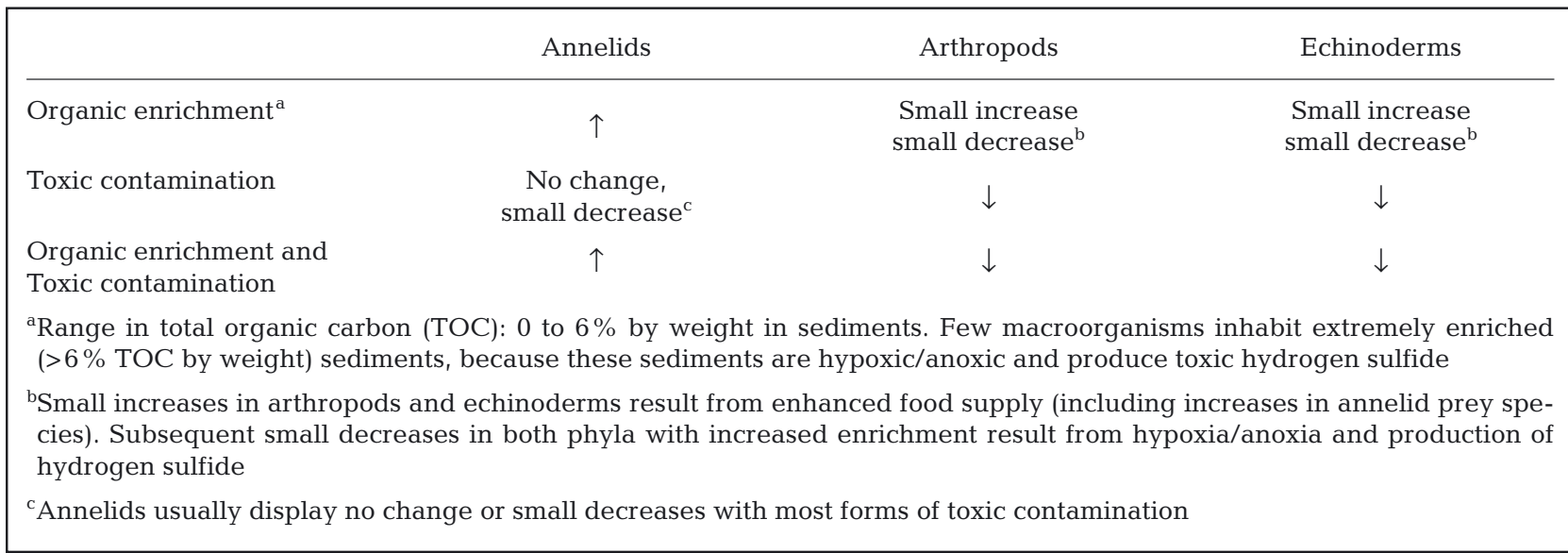


difficult to identify, there may be natural history information on community structure for the contaminated site that can help identify a baseline community (i.e. temporal control) that existed prior to contamination. In addition, there is a huge volume of literature available describing the general community patterns that are to be expected for a given set of environmental conditions (e.g. Lenihan \& Micheli 2001).

\section{Ecological significance}

A major conclusion of our study is that the direct effects of chemical contaminants on soft-sediment infaunal community structure appear clearly, unconfounded by indirect biological interactions that would probably prevent such inference in other marine communities. For example, a long history of experimental work indicates that indirect biological effects (e.g. where the effects of one species on a second species are mediated by a third species) have a major influence on community structure in rocky intertidal systems (e.g. Paine 1966, Menge 1995, Menge \& Branch 2001, and see Micheli et al. 2002 for a recent example in the deep sea). Indirect biological effects can also help structure soft-sediment communities (Ambrose 1984, 1991), although the universality of their importance has yet to be proven (Olafsson et al. 1994). We found that, in spite of potential indirect effects of predation, biological disturbance, competition, and positive interactions, the direct effects of the 2 major pollutant types (organic enrichment and toxicants) were obvious in Antarctic benthic soft-sediment communities. Whether the same pattern exists in temperate or tropical latitude communities is untested but is probable because many of the phyla, families, and genera that colonized our experiments are also found in soft-sediment communities worldwide. Our finding is a significant ecological discovery because it provides yet another example of how functionally different soft-sediment communities are compared with communities in the rocky intertidal. Prior work by Peterson (1979) showed that competitive exclusion rarely determines soft-sediment community structure as it does so commonly in the rocky intertidal (Menge \& Branch 2001). Results of our experiment underscore another potentially important difference between the 2 systems: soft-sediment communities are less susceptible to variation due to indirect biotic interactions than rocky intertidal communities.

Acknowledgements. This project was funded by National Science Foundation Grant OPP-59088 to C.H.P. and H.S.L. Further support was provided by the US Minerals Management Service and the Pew Foundation. We thank R. Robbins, R. Score, and many others at the Crary Environmental Science Center at McMurdo Station for help in various aspects of this study. J. Byers, L. Hill, and M. Paddock helped by scubadiving and conducting laboratory work. A. Bonnema, J. Geotzl, E. Landrau, C. Roberts, M. Stephenson, and others at the Moss Landing Marine Pollution Studies Laboratory conducted chemical analyses. D. Colby helped with statistical analyses, and S. Anghera, M. Kay, F. Micheli, W. Murdoch, P. Kareiva, S. Powers, M. Piehler, E. Sotka, and 3 anonymous reviewers helped improve the manuscript.

\section{LITERATURE CITED}

Ambrose WG Jr (1984) Role of predatory infauna in structuring marine soft-bottom communities. Mar Ecol Prog Ser 17:109-115

Ambrose WG Jr (1991) Are infaunal predators important in structuring marine soft-sediment communities? Am Zool 31:849-860

Bryan GW, Langston WJ (1992) Bioavailability, accumulation, and effects of heavy metals in sediments with special reference to United Kingdom estuaries. Environ Pollut 76:89-131

Clarke RB, Frid C, Attrill M (1997) Marine pollution. Oxford University Press, Oxford

Dayton PK, Oliver JS (1977) Antarctic soft-bottom benthos in oligotrophic and eutrophication environments. Science 197:55-58

Dayton PK, Robilliard GA, DeVries AL (1969) Anchor ice formation in McMurdo Sound, Antarctica and its biological effects. Science 163:273-275

Dayton PK, Robilliard GA, Paine RT, Dayton LB (1974) Biologial accommodation in the benthic community of McMurdo Station, Antarctica. Ecol Monogr 44:105-128

Diaz RJ, Rosenberg R (1995) Marine benthic hypoxia: a review of its ecological effects and the behavioral responses of benthic macrofauna. Oceanogr Mar Biol Annu Rev 33:245-303

Fauchauld T (1977) The polychaete worms. Nat Hist Mus Los Angeles Sci Ser 28:1-188

Fenchel T, Bernard C (1995) Mats of colourless sulphur bacteria. 1. Major microbial processes. Mar Ecol Prog Ser 128: 161-170

Fenchel T, Riedl RJ (1970) The sulfide system: new biotic community underneath the oxidized layer in marine sand bottoms. Mar Biol 7:255-268

Furness RW, Rainbow PS (1990) Heavy metals in the marine environment. CRC Press, Boca Raton, FL

Giere O, Preusse JH, Dubilier N (1999) Tubificiodes benedii (Tubificidae: Oligochaeta) - a pioneer in hypoxia and sulfidic environments: an overview of adaptive pathways. Hydrobiologia 406:235-241

Grassle JF, Grassle JP (1974) Opportunistic life histories and genetic systems in marine benthic polychaetes. J Mar Res 32:253-284

Gray JS (1974) Animal-sediment relationships. Oceanogr Mar Biol Annu Rev 12:223-261

Gray JS, Clarke KR, Warwick RM, Hobbs G (1990) Detection of initial effects of pollution on marine benthos: an example from the Ekofisk and Eldfisk oilfields, North Sea. Mar Ecol Prog Ser 66:285-299

Heip C, Vincx M, Vranken G (1985) The ecology of marine nematodes. Oceanogr Mar Biol Annu Rev 23:399-489

Howington JP, McFeters GA, Barry JP, Smith JJ (1992) Distribution of the McMurdo Station sewage plume. Mar Pollut Bull 25:324-327

James MO (1989) Biotransformation and disposition of PAH in aquatic invertebrates. In: Varanasi U (ed) Metabolism of polycyclic aromatic hydrocarbons in the aquatic environment. CRC Press, Boca Raton, FL, p 69-91 
Kowallik U, Pringshe EG (1966) Oxidation of hydrogen sufide by Beggiatoa. Am J Bot 53:801-811

Lenihan HS (1992) Benthic marine pollution around McMurdo Station, Antarctica: a summary of findings. Mar Pollut Bull 25:318-323

Lenihan HS, Micheli F (2001) Soft sediment communities. In: Bertness, MD, Gaines, SD, Hay ME (eds) Marine community ecology, Sinauer Associates, Sunderland, MA, p 253-287

Lenihan HS, Oliver JS (1995) Natural and anthropogenic disturbances to marine benthic communities in Antarctica. Ecol Appl 5:311-326

Lenihan HS, Oliver JS, Oakden JM, Stephenson MD (1990) Intense and localized marine pollution around McMurdo Station, Antarctica. Mar Pollut Bull 21:422-430

Lenihan HS, Kiest KA, Conlan KE, Slattery PN, Konar BH, Oliver JS (1995) Patterns of survival and behavior in Antarctic benthic invertebrates exposed to contaminated sediments: field and laboratory bioassay experiments. J Exp Mar Biol Ecol 192:233-255

Long ER (2000) Degraded sediment quality in US estuaries. Ecol Appl 10:338-349

Long ER, Chapman PM (1985) A sediment quality triad: measures of sediment contamination, toxicity, and infaunal community composition in Puget Sound. Mar Pollut Bull 16:405-413

Marcano L, Nusetti O, Rodriquez-Grau J, Vilas J (1996) Uptake and depuration of copper and zinc in relation to metal-binding protein in the polychaete Eurythoe complacata. Comp Biochem Phys C 114:179-184

Maurer D, Nguyen H, Robertson G, Gerlinger T (1999) The Infaunal Trophic Index (ITI): its suitability for marine environmental monitoring. Ecol Appl 9:699-714

Menge BA (1995) Indirect effects in marine rocky intertidal interactions webs: patterns and importance. Ecol Monogr 65:21-74

Menge BA, Branch GM (2001) Rocky intertidal communities. In: Bertness MD, Gaines SD, Hay ME (eds) Marine community ecology. Sinauer Associates, Sunderland, MA, p 221-251

Micheli F, Peterson CH, Mullineaux LS, Fisher CR, Mills SW, Sancho G, Johnson GA, Lenihan HS (2002) Predation structures communities at deep-sea hydrothermal vents. Ecol Monogr 72:365-382

Nassir Y, Rainbow PS, Amiard-Triquet C, Rainglet F, Smith BD (2000) Trace-metal detoxification in the ventral caeca of Orchestia gammarellus (Crustacea: Amphipoda) Mar Biol 136:474-484

NRC (National Research Council) (1990) Managing troubled waters: the role of marine environmental monitoring. National Academy Press, Washington, DC

Oakden JM, Oliver JS, Flegal AR (1984a) EDTA chelation and zinc antagonism with cadmium in sediment - effect on the behavior and mortality of two infaunal amphipods. Mar Biol 84:125-130

Oakden JM, Oliver JS, Flegal AR (1984b) Behavioral responses of a phoxocephalid amphipod to organic enrichment and trace metals in sediment. Mar Ecol Prog Ser 14: 253-267

Olaffsson EB, Peterson CH, Ambrose WG Jr (1994) Does recruitment limitation structure populations and communities of macro-invertebrates in marine soft sediments: the relative importance of pre- and post-settlement processes. Oceanogr Mar Biol Annu Rev 32:65-109

Oliver JS, Slattery PN (1985) Effects of crustacean predators on the species composition and population structure of soft-bodied infauna from McMurdo Station, Antarctica. Ophelia 24:155-175

Editorial responsibility: Otto Kinne (Editor),

Oldendorf/Luhe, Germany
Paine RT (1966) Food web complexity and species diversity. Am Nat 100:65-75

Pearson TH, Rosenberg R (1978) Macrobenthic succession in relation to organic enrichment and pollution of the marine environment. Oceanogr Mar Biol Annu Rev 16:229-311

Peterson CH (1979) Predation, competitive exclusion, and diversity on soft-sediment benthic communities of estuaries and lagoons. In: Livingston RJ (ed) Ecological processes in coastal marine systems. Plenum Press, New York, p 233-264

Peterson CH (2001) The 'Exxon Valdez' oil spill in Alaska: acute, indirect, and chronic effects on the ecosystem. Adv Mar Biol 38:1-103

Peterson $\mathrm{CH}$, Kennicutt MC II, Green $\mathrm{RH}$, Montagna $\mathrm{P}_{\mathrm{r}}$ Harper DE Jr, Powell EN, Roscigno PF (1996) Ecological consequences of environmental perturbations associated with offshore hydrocarbon production: a perspective on long-term exposures in the Gulf of Mexico. Can J Fish Aquat Sci 53:2637-2654

Raffaelli DG, Mason CF (1981) Pollution monitoring with meiofauna using the ratio of nematodes to copepods. Mar Pollut Bull 12:158-163

Risebrough RW, DeLappe BW, Younghanshaug C (1990) PCB and PCT contamination in Winter Quarters Bay, Antarctica. Mar Pollut Bull 21:523-529

Schmitt RJ, Osenberg CW (1996) Detecting ecological impacts: concepts and applications in coastal habitats. Academic Press, San Diego

Somerfield PJ, Clarke KR (1995) Taxonomic level in marine community studies revisited. Mar Ecol Prog Ser 127: 113-119

Steichen DJ, Holbrook SJ, Osenberg CW (1996) Distribution and abundance of benthic and demersal macrofauna within a natural hydrocarbon seep. Mar Ecol Prog Ser 138:71-82

Underwood AJ, Peterson CH (1988) Toward an ecological framework for investigating pollution. Mar Ecol Prog Ser 46:227-234

US EPA (US Environmental Protection Agency) (2000) Ecological risk assessment. Office of Research and Development: National Center for Environmental Assessment, Washington, DC; available at: www.epa.gov/ncea/ecologic.htm

Vitousek PM, Mooney HA, Lubchenco J, Melillo JM (1997) Human domination of earth's ecosystems. Science 277 494-503

Völkel S, Grieshaber MR (1997) Sulphide oxidation and oxidative phosphorylation in the mitochondria of the lugworm Arenicola marina. J Exp Biol 200:83-92

Wallace WG, Lopez GR, Levinton JS (1998) Cadmium resistance in an oligochaete and its effect on a cadmium trophic transfer to an omnivorous shrimp. Mar Ecol Prog Ser 172:225-237

Wallace WG, Brower TMH, Brower M, Lopez GR (2000) Alterations in prey capture and induction of metallothioneins in grass shrimp fed cadmium-contaminated prey. Environ Toxicol Chem 19:962-971

Warwick RM (1986) A new method for detecting pollution effects on marine macrobenthic communities. Mar Biol 92: $557-562$

Warwick RM (1988) Analysis of community attributes of the macrobenthos of Frierfjord-Langesundfjord at taxonomic levels higher than species. Mar Ecol Prog Ser 46:167-170

Warwick RM, Clarke RB (1993) Comparing the severity of disturbance: a meta-analysis of major macrobenthic community data. Mar Ecol Prog Ser 92:221-231

Widdows J (1985) Physiological response to pollution. Mar Pollut Bull 16:129-139

Submitted: January 23, 2002; Accepted: August 19, 2003

Proofs received from author(s): September 23, 2003 